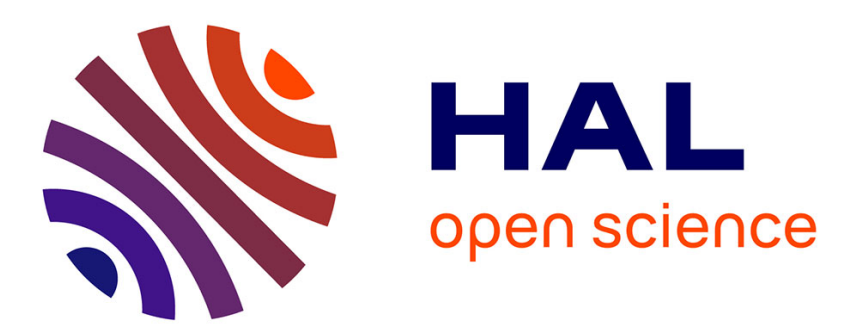

\title{
Perception by French students of the gendered nature of material artifacts studied in technology education
}

\author{
Colette Andreucci, Marjolaine Chatoney
}

\section{To cite this version:}

Colette Andreucci, Marjolaine Chatoney. Perception by French students of the gendered nature of material artifacts studied in technology education. International Journal of Technology and Design Education, 2017, 27, pp.1-18. 10.1007/s10798-015-9329-9 . hal-02473439

\section{HAL Id: hal-02473439 \\ https://hal-amu.archives-ouvertes.fr/hal-02473439}

Submitted on 10 Feb 2020

HAL is a multi-disciplinary open access archive for the deposit and dissemination of scientific research documents, whether they are published or not. The documents may come from teaching and research institutions in France or abroad, or from public or private research centers.
L'archive ouverte pluridisciplinaire HAL, est destinée au dépôt et à la diffusion de documents scientifiques de niveau recherche, publiés ou non, émanant des établissements d'enseignement et de recherche français ou étrangers, des laboratoires publics ou privés. 


\title{
Perception by French students of the gendered nature of material artifacts studied in technology education
}

\author{
Andreucci Colette $^{1} \cdot$ Chatoney Marjolaine $^{2}$
}

\begin{abstract}
Many studies have shown the importance of the socio-cultural factors that lead girls to desert scientific and technological courses. Over a long period, the contents of the French technology education (TE) college curricula may well have contributed to strengthening the feeling among girls that this discipline was better suited to boys. The choice of technical artifacts that embody the knowledge taught could be partially responsible for this. Our investigation was conducted in two stages. Firstly, we made an inventory of artifacts presented in four TE schoolbooks for the 6th grade. Secondly, we submitted this list to a population of 98 girls and boys (12-14 years). Our results indicate that most of these artifacts were categorized as mixed. However, those that are classed as masculine are more numerous than feminine one's. They are also more prevalent among girls and their number increases with age. The grouping of these artifacts by families also shows gender differences.
\end{abstract}

Keywords Technology education - Gender - Artifact - School-books · Categorization · Stereotype

\section{Introduction}

Only natural and biological objects have a sex related to their reproductive function. Obviously, this ontological characteristic distinguishes between natural and artificial objects. However, it can be considered that many technical artefacts are gendered from

Chatoney Marjolaine

marjolaine.chatoney@univ-amu.fr

Andreucci Colette

colette.andreucci@ens-lyon.fr

1 Aix-Marseille Université, ENS Lyon, ADEF EA 4671, 13248 Marseille, France

2 Aix-Marseille Université, ADEF EA 4671, 13248 Marseille, France 
different points of view. Some are gendered in their design: for example, some cars are especially designed to suit females. In this case, gender concerns the design and diversification of the commercial offer according to men and women's particular tastes. Another dimension of the gendered characteristic of technical artefacts concerns their social use and the cultural division of social roles between men and women in society. This aspect is more generic because it deals with categories of artefacts (cars, for example) rather than specific entities of a given category (minis vs four-by-fours).

Do artifacts have gender? The answer is "yes they do " [...]" Artifacts do have gender and gender politics in the sense that they are designed and used in gendered contexts" (Berg and Lie 1995, p. 347). For Persson (2010), artefacts reflect our thinking about gender. But what is the student's opinion about this question?

Are there many gendered categories of objects in the minds of children? Surely toys at least play a very early role. Young girls and boys perceive them as appropriate or not to their own sex; but boys' toys seem better suited for scientific and technical awakening than girls' toys, that mainly encourage the development of social skills (Caleb 2000; RuelTraquet 2010). What about the other categories of artefacts? The purpose of this paper is to shed light on this question by taking account of the artefacts that illustrate technology education textbooks. Our study therefore also provides answers to other questions: what are the technical artefacts in textbooks? How are these objects representative of girls' and boys' technology interests considering that girls generally have little interest in electricity, energy, electronics, car engines, space travel and nuclear weapons and boys have little interest in topics concerning the development and care of people, health and food (Mottier 1997, p. 26)?

\section{Theorical background}

\section{Why gender and not sex?}

The concept of sex refers to the biological differences (i.e. innate) between men and women. In contrast, the term "gender" is associated with sociocultural differences between the sexes (i.e. transmitted and acquired as a result of the environment in which people live) and linked to the "effects of institutions, practices, discourses with multiple and diffuse points of origin" (Butler 1990, preface, ix).

The distinction between sex and gender was introduced for the first time, in 1915, in the context of psychiatric studies on hermaphroditism. The current meaning of the word 'gender was defined in 1962 by the Oxford English Dictionary, explaining that gender refers to the social and cultural aspects of sex. In 1972, the sociologist Ann Oakley, in the book Sex, Gender \& Society, introduced the concept into feminist studies that evolved into the current field of gender studies, developed largely in the 1980s.

The theme of gender relates to most social science fields (literature, history, economics, arts and, of course, also technology) in that it is the subject of a highly diverse and specific international literature.

The gender issue also applies to most areas in the humanities (literature, history, economics, arts and, of course, also technology) illustrated by a very abundant international literature.

Thus, many researchers have contributed to illuminate the manifestations and effects of gender (including stereotypes) and its mechanisms that are situated at different levels: societal, symbolic and individual (Harding and McGregor 1996). 


\section{Gender and education}

In the field of education, the gender issue was also widely investigated by English-speaking sociologists (Bose and Peter 1983; Ezzell 2009; Lorber 1994; Oakley 1972; Simon and Leda 2004) and francophones (Baudelot and Establet 1992; Boudon 1973; Bourdieu and Passeron 1970; Duru-Bellat 2005; Marry 2004; Mosconi 1994) because of the differentiated orientation of girls and boys in the literary and scientific and technological sectors.

Many studies contribute to show that parents, teachers and also the media sensitize children to specific and appropriate roles and standards for each sex. This internalization is influenced by girls' and boy's toys, parent's expectations and encouragement to succeed in particular subjects and so on (Fleer and Jane 2004; Petrina 2007).

In the field of science education we find more specific studies that concern all school subjects. These studies show in each area of learning (curriculum, elitism, pedagogical methods, teachers' ideology, etc.) that characteristics induce or reinforce gender effects. In mathematics, for example, it has been shown (Lorenzi-Cioldi 1991) that girls receive more approval, less criticism and less solicitation. This lesser requirement is, in addition, internalized by girls as reflecting their lower capacities. So these students' identity is associated with lower self-esteem in mathematics and science.

In technology, the gender issue is particularly problematic for several reasons: the persistent disaffection with the scientific and technological sectors by girls (Harding and McGregor 1996; Rosenwald 2006; UNESCO 2007); the many negative stereotypes surrounding women's attitudes towards technology (Autio 2013; Dagiral 2006; Grint and Rosalind 1995); and the domination of male social groups in many technology sectors, with the exception of the domestic field (Bijker 1995; Griffin 1984; Zuga 1996). A World Bank Discussion Paper 'Women's Access to Higher Education' (1994), noted that the nature and practice of sciences \& technology projects a masculine image, not only because men still dominate the field, but also because men dominate the language and images found in scientific literature: exclusionary language in textbooks and lectures, reinforced by illustrations that emphasize almost exclusively the role of men in science, serves to project and perpetuate stereotypical images and biased behaviors (World Science Report 1996; p. 310).

\section{Technology and society studies}

From the 1980s onwards, the relationship between gender and technology has become a source of debate in the fields of science and Technology and Society Studies (Gill and Grint 1995; Law 1991; McKenzie and Wagcman 1999; Oldenziel 2003) that are also interested in production technology, reproduction technology (Griffin 1984), new technology and domestic technology. The study by Cockburn and Ormord (1993) questions the place of men and women at different stages of the life cycle of the microwave (design, production, marketing and use). It shows that men occupy managerial and engineering positions and have more valued technical knowledge, while claiming recognition of the kitchen as a technological activity, that allows the authors to break the equation 'microwave domestic $=$ women $=$ of little importance'. The stereotypes about women in technology continue to spread, while the figures of the engineer or computer scientist present themselves as largely and inherently male.

Historically, technical activities of man are considered to relate to technology and engineering, while female activities concern craft and homemaking (Stanley 1993). The 
concept of technology is based on male activities and traditions and affects the design and development, diffusion and use of artefacts and technologies (Oudshoorn et al. 2004; Wajcman 2000, 2004).

\section{Gender and technology education}

Mosconi (1994) shows that when girls engage in typically male industrial technology sectors, they endure bullying: "It takes being courageous to make technical profession as a woman, you have to fight for success" (Mosconi and Delanote 2003, p. 88).

Many studies have been developed to try to identify the causes of this disaffection and propose a remedy. Among the causes, researchers are interested in very different aspects: sociocultural effects on education, effects of language learning, effects of the familiarity of students with technical language, effect of teaching methods and practices of classes and effect of teacher training.

Several studies show that gender stereotypes appear very early in the field of technology education (Nisbet et al. 1998; Turja et al. 2009). Children's literature used at primary school contributes to the gendered image and social roles that children build. It also limits their interests to domestic and professional activities that are not related socially to their own sex (Schultz et al. 1995).

Concerning activities offered to students, girls and boys have respectively specific expectations (Rothschild 1988; Sadker and Silber 2007; Weber and Custer 2005). According to these authors, curriculum design should further take into account content affecting girls and boys.

In sciences and particularly in biology, we know that the content of textbooks is gendered (Caravita et al. 2008; Castéras et al. 2008). But in technology these types of studies are missing for middle school. There is little comparative qualitative and significant data available (Ginestié 2005; Roustan-Jalin et al. 2002), regarding phenomena surrounding relationships between gender and teaching content; gender and types of activities; gender and forms of study; gender and teachers' actions; gender and academic structure and so on. As a result, it is not known, for instance, whether certain content, types of activities, forms of study, teaching traits and academic structures are more suitable for girls than boys and vice versa. However we know that gendered study materials have an important effect on pupil behavior (Chatoney and Andreucci 2009). Girls prove to be more sensitive than their male counterparts to the study aids they are working with. They show imagination and inventiveness, taking more risks than boys with the feminine familiar material. They act in a similar way to boys when working with masculine materials. Feminizing technology by opening it up to more feminine fields such as habitat, clothes or food whilst not taking anything away from learning for boys. It would probably be a solution for reuniting girls with technology by ensuring that this subject area allows them to make the most of their inventive and creative skills (Chatoney and Andreucci 2009).

In our article the question of gender is studied from the point of view of the artifacts that illustrate schoolbooks. Are these artifacts non-gendered or representative of each gender? A large number of technical objects are used to illustrate the content of school books. These artifacts are presented alone or in context of use. The contents of these books change with each new curriculum. Are these evolutions in line with a better balance between objects seen as feminine and those considered masculine? This paper presents two empirical studies involving middle school pupils to inform these issues.

Various works are concerned with gender stereotypes in school textbooks in many disciplines and also in technology education (Evan and Davies 2000; Jackson and Gee 
2005). As Blumberg points out (2007, p. 2) "it is time to strip the camouflage off the hidden obstacle of gender bias in learning materials". With regard to technology, studies are scarcer or relate to primary school if on children's literature (Knopke 2014). For Mottier (1997, pp. 25-26), "Textbooks must show that diverse raw materials can be used in technology [...] must take examples not only from the sphere of life of man, but also from spheres interesting to both women and men. [...] must show that technology is an aspect of human activity not an autonomous phenomenon from outside. [...] must make clear that technical occupations can be held by both men and women."

Research of Brugeilles and Cromer (2011) shows the presence of more male figures and the prevalence of stereotypical portraits according to the sex of the adult depicted. However, when children are depicted, gender is more balanced.

Technical artifacts are by essence the product of human nature. Studies on the categorization of artifacts show that the relationship between function of use and structure is essential from the point of view of understanding. There are many objects whose use refers to privileged users (for children it is obvious!). For other objects product design takes into account their social use so the objects are socially determined for commercial purposes. Either they are neutral from the point of view of gender or they are gendered. Furthermore, the social and cultural distribution of activities between men and women can also lead to a gendered vision of technical objects according to their predominant users. So, usually is not from the point of view of their design that artifacts such as a tube of lipstick or a fishing rod, supposedly being better applied to men or women; but because of their link with to a feminine or masculine activity.

\section{l'ET en France}

Technology education in France is compulsory for all pupils from 3 to 15 years of age. At elementary level (3-11 years), scientific and technological education are combined. Later (for 12-15 years old) technology education becomes a discipline in its own right.

Contents of technology education is defined by national curriculum, that specifies for each cycle and each level the objectives, competences, contents and the suitable teaching approach. The curriculums are renovated every 10 years according to educational policy and the social evolutions (new knowledge, discoveries, and evolution of the references and contents of employment). In secondary education (11-14 years old), the first curriculum of technology date back to 1985 . At that period the teaching is centered on 10 steps of industrial project approach (needs studies, designing, manufacturing, marketing, recycling, etc.). In 1995, activities are realized through: electronic construction, shape of materials, marketing and ICT. From 2005, activities concern the applied field of transportation (functioning of a technical object, materials, energy, evolution of technical objects, ITC.).

\section{Method}

\section{Characteristics of the studied schoolbooks}

Technology textbooks selected for this study are intended for 11-12-year-old pupils (secondary school, year 7). We made this choice because it is at this level that the ET becomes a field of autonomous learning and students discover associated study materials. Before that, during primary school, the curriculum combines science and technology 
learning. The facts, however, show that this disciplinary diversity comes at the expense of technology. The actual time allocated to these two areas is unequal Elementary school teachers are predominantly women from literary studies who feel inadequately trained to practice classroom activities in technology. In addition, at this level technical artifacts are poorly represented in textbooks compared to natural objects related to scientific discovery. In contrast, year 7 textbooks offer the benefit of being the first specific textbooks through students build a first image of the sphere artifacts on ET is likely to be focused.

Furthermore, we decided to take into account schoolbooks published at several year intervals (see Table 1 below) and over a period of 20 years. Our concern is to extend the sphere of illustration of artifacts used over a long period to reveal the evolution of the ET curriculum. A single publisher offers Technology Education from its origin in the French curriculum to the present for this grade level. For this reason the study focuses on four textbooks from this publisher.

These various dates correspond to the successive stages of the history of technology education that marks the evolution of its knowledge content. Thus, in 1986 technology 'takes its first steps' in the sense that the discipline has just been introduced into the curriculum under this name, replacing EMT (manual and technical education). Ten years later, in 1996, curriculum was modified. From this point on it was broken up into four distinct parts: working of materials, electronic construction, marketing of a product and textual information processing 1 . In 2005, the whole of the program for 11-12-year-olds was reorganized with a focus on the themes of transport, three activities (design, production and communication) and two central concepts (materials and energy).

\section{Procedure of categorization of artifacts illustrating technological education in four schoolbooks}

Usually, studies on gender stereotypes in textbooks relate to the characteristics of the individual domestic and professional occupations represented in the illustrations. In the manuals that we examined, we found very few pictures of men or women in activities. This may be related to the desire to specifically avoid gender stereotypes that are linked to the domination of men in many industrial trades. This is probably also linked to the weakly relation of technology contents with human activities. In the light of these findings we made the choice to focus on technical artifacts depicted but often not presented in context of design, production or use.

For each schoolbook we carried out an exhaustive inventory of artifacts (figurative photographs and drawings). A list of all distinct objects was established with their respective occurrence (how many times each object is represented). The results of this first census (Table 2 show that the first schoolbook (published in 1986, i.e. only 1 year after the

Table 1 Specifications of studied schoolbooks

\begin{tabular}{lllc}
\hline Year of publication & Title & Authors & No. of pages \\
\hline 1986 & Technology with the College: Level 1 & Biancotto A., \& Boye P. & 127 \\
1996 & Technology 6 & Pawl J., \& Gaigher G. & 127 \\
2000 & Tools and Concepts_Technology & Pawl J., \& Gaigher G. & 127 \\
2005 & Eureka Technology!-Technology 6 & Pawl J., \& Gaigher G & 159 \\
\hline
\end{tabular}


Table 2 Number of illustrations of objects represented in the various schoolbooks

\begin{tabular}{lcc}
\hline & Number of illustrations & Number of distinct artifacts \\
\hline Schoolbook 1 & 55 & 32 \\
Schoolbook 2 & 202 & 120 \\
Schoolbook 3 & 180 & 109 \\
Schoolbook 4 & 164 & 75 \\
\hline
\end{tabular}

implementation of the discipline) was very poorly illustrated; only 32 distinct objects were present, including three artifacts with an occurrence higher than the others: the electronic component (six times), the computer (five times) and the multi-meter (five times). The two following schoolbooks (the 1996 and 2000 editions) are, at first sight, rather quantitatively and qualitatively similar in terms of illustrations: the objects most frequently represented are the computer (eight times in both cases) and the electronic component (five times and eight times). Finally, it is noted that the most recent handbook (2005 edition) contains a smaller number of artifacts and the theme of transport is dominant here (the bicycle, 19 times; the boat, 14 times and the car, 12 times).

After eliminating artifacts presented several times, we obtained 167 different objects were culled from all four editions.

\section{Categorization of the artifacts by the pupils}

Technology is permeated from end to end with social, psychological, aesthetic, political, economic and, first and foremost, human links. In this sense, man-made things are not neutral (Akrich 1992, 1995; Latour 1987). For the designers themselves, it is sometimes difficult to ignore the gender target users. Configuring the user as 'everybody' is not always evident for them. Oudshoorn et al. (2004) argue in this way that we need to take into account the gender identity of designers to understand how design practices in ICT prioritize male users. Specifically, it is because we believed that the objects were simply fitted with a utilitarian function that a neutrality was assigned to tools.

Obviously, the use of certain objects is preferentially reserved for women (for example, items of make-up) while others (for example, fishing apparatus) are primarily intended for men. However this criterion of use (or the frequency of the relationship of men and women with such and such an object) remains ambiguous most of the time. For example, a car does not have a reason to be gendered given that there are as many drivers of both sexes. On the other hand, if one looks at the car from the point of view of the sex of the people who conceive it and repair it, or who read specialized car magazines, the relationship with cars appears wider among men than among women. So, it is difficult to carry out a categorization a priori of the artifacts. Furthermore, let us note that contrary to English, in French the names of objects are themselves gendered. Some names are masculine (e.g. a bicycle, a settee, etc.) and others are feminine (a pan, a dress, etc.). However, it does not assume anything about the gender of the users of the objects, as testified in other examples, for example a crane, an excavator, nail varnish, hair curlers and so on.

On this question, the point of view of the students should be taken into account as they are the main users of textbooks. So, in order to clarify how pupils conceive the gendered 
character of artifacts presented in technology schoolbooks, we conducted a preliminary study.

\section{Sample}

A group of 98 pupils took part in this study on the categorization of artifacts. This sample includes forty boys ( 20 of 12 years old, 20 of 14 years old) and 58 girls (29 of 12 years old, 29 of 14 years old). The number of girls and boys is not balanced because it corresponds to the natural groups (technology classes) to which we had access. Because of the differing size of the groups of girls and boys, the reporting of findings indicate the number of instances of answers but also the percentages associated.

The sample is thus composed of four independent groups of pupils. The task submitted to the pupils (see questionnaire in "Appendix") consists of indicating whether the 167 artifacts (alphabetically listed) are more for boys, girls or for both. More precisely, pupils received the following instructions: 'For each quoted object, indicate, whether, according to you, it corresponds more to an object for girls $(\mathrm{F})$, boys $(\mathrm{G})$ or for girls as well as boys $(\mathrm{F}+\mathrm{G})^{\prime}$. The pupils were required to simply put a cross in the ad hoc column $(\mathrm{F}, \mathrm{G}$ or $\mathrm{F}+\mathrm{G})$. A final column "?" is reserved for unknown objects by pupils. Thus, each pupil formulated 167 judgements whose analysis is presented below.

\section{Data analysis and results}

\section{Distribution of boys' and girls' judgments at each age}

First, we can see (Table 3) that the majority of objects represented in the schoolbooks are considered as not gendered by each group of students. We observe also that neutral objects are estimated at each age exactly in the same proportion by girls and boys (around $66 \%$ at 12 years old and $58 \%$ at 14 years old). Furthermore, we notice a same tendency among girls and boys: with age the number of these neutral objects regresses systematically and significantly for students of each sex:

- For girls $66.49 \%$ at 12 years old versus $58.15 \%$ at 14 years old (khi $2=68.32$, sign .001)

Table 3 Distribution of the various types of judgments within the four groups

\begin{tabular}{|c|c|c|c|c|}
\hline \multirow[t]{2}{*}{ Objects for } & \multicolumn{2}{|l|}{ Girls } & \multicolumn{2}{|l|}{ Boys } \\
\hline & $\begin{array}{l}12 \text { years } \\
(\mathrm{N}=29)\end{array}$ & $\begin{array}{l}14 \text { years } \\
(\mathrm{N}=29)\end{array}$ & $\begin{array}{l}12 \text { years } \\
(\mathrm{N}=20)\end{array}$ & $\begin{array}{l}14 \text { years } \\
(\mathrm{N}=20)\end{array}$ \\
\hline Both sexes & $3220(66.49 \%)$ & $2816(58.15 \%)$ & $2188(66.49 \%)$ & $1944(58.20 \%)$ \\
\hline Girls & $442(9.12 \%)$ & $475(9.80 \%)$ & $174(5.21 \%)$ & $305(9.13 \%)$ \\
\hline Boys & $625(12.91 \%)$ & $994(20.53 \%)$ & $605(18.11 \%)$ & $812(24.31 \%)$ \\
\hline I do not know the object & $541(11.18 \%)$ & $547(11.30 \%)$ & $365(10.93 \%)$ & $274(8.20 \%)$ \\
\hline Non-responses & $15(0.30 \%)$ & $11(0.22 \%)$ & $8(0.24 \%)$ & $5(0.15 \%)$ \\
\hline Total answers & $4843(100 \%)$ & $4843(100 \%)$ & $3340(100 \%)$ & $3340(100 \%)$ \\
\hline
\end{tabular}


- For boys $66.49 \%$ at 12 years old versus $58.20 \%$ at 14 years old (Khi $2=37.77$ sign $.001)$.

So, under the effect of age, neutrality attributed to objects become less obvious for the students.

Secondly, inside each group the comparison of the proportion of artifacts identified as male and female reveals another systematic difference: schoolbooks contain more objects made for boys than objects made for girls according to girls and boys aged 12 and 14 years.

- For girls $12.91 \%$ versus $9.12 \%$ at 12 years old (khi $2=35.27$; sign .001) and $20.53 \%$ versus $9.80 \%$ (khi $2=16.27$; sign .001 ) at 14 years old

- For boys $18.11 \%$ versus $5.21 \%$ at 12 years old (khi $2=269,94$, sign .001) and $24.31 \%$ versus $9.13 \%$ at 14 years old (khi $2=76.33$; sign .001 ).

So, in the opinion of the four groups of students, schoolbooks contain more technical artifacts likely to concern boys than technical artifacts likely to concern girls.

By contrast, several relevant differences can be seen in the distribution of the various types of judgments inside the four groups. In detail, the evolution of girls' and boys' judgments according to their age shows the following facts:

Among boys, we observe that the percentage of artifacts considered as feminine increases with age $(5.21 \%$ at 12 years vs $9.13 \%$ at 14 years, khi $2=38.08$ sign.001). The same result applies to the objects considered to be masculine: $18.11 \%$ of answers at 12 years compared with $24.31 \%$ at 14 years (Khi $2=37.69$ sign. 001).

So, between 12 and 14 years, the boys become more and more discriminatory or sensitive to the fact that many technical artifacts are sexually marked.

Among girls, we note no significant evolution according to the age for objects considered to be feminine $(9.12 \%$ vs $9.80 \%$, Khi $=1.13$, ns). But, in contrast the number of objects considered as masculine increases considerably between 12 years (626 answers out of 4843 ) and 14 years (994 answers, Khi $=102.06$, sign. 001). So, the sensitivity of girls to the gendered character of the artifacts also increases with age, but in a selective way. The artifacts categorized as masculine by girls increases with age whereas those categorized as feminine remains stable.

So, between 12 and 14 years, girls also perceive more and more the masculinity (but not to the femininity) of the technical artifacts contained in schoolbooks.

The previous result can be explained by the initial difference that exists between girls and boys. Indeed, at 12 years old objects considered as feminine are significantly more numerous for girls (9.12 \% vs 5, $21 \%$ for boys, khi $=45.66$ sign. 001). Among girls this percentage remains stable while it increases relevantly with age for boys. Lately, the proportion of artifacts that pupils find as feminine is the same (about $10 \%$ ) for all students. A homogenization of opinions can be seen through the age effect. Does the opposite tendency exist for the objects considered as masculine? The answer is yes. At 12 years, the objects are regarded as masculine more often by the boys than by the girls (khi $2=41.98$, sign. 001). Thus, at this age, the girls judge an average of 21.5 objects on the list as masculine against more than 30 objects on average among the boys. This tendency persists at 14 years: there are more answers in favor of the masculinity of the objects among boys than girls (Khi $2=16.48$ sign. 001). Furthermore, this phenomenon is reinforced with age: 34 objects of the list on average at the girls and a little 40 among boys.

Also, we note that unknown objects are very numerous. It indicate that the nomination of technical artifact is little mastered by students and must be teach to be learnt. Indeed, it is not very surprising because of the specialized language in the field of technology. 
Furthermore, this technical vocabulary is few mediated by ordinary culture. For example: still, photo developer, Chinese abacus, spool, thrust bloc, dynamotor, anvil, mechanical press, minitel (French ancestry of internet), oscilloscope, 3 wheels bike and typon. Many of these objects are old or fall within professional environment hyper specialized.

Between 12 and 14 years the proportion of unknown objects by the girl's remains constant (11\%/167 objects). At 12 years, this proportion is the same for boys and girls. But at 14 years this proportion is fewer among the boys than the girls $(8.20 \% / 11.30 \%$; khi $2=20.92$; sign .001). So, the familiarity of artifacts represented in schoolbooks progress among boys but not among girls.

The non-responses are in very restricted numbers, showing that students responded to the survey with great care.

\section{Objects clearly gendered}

We can consider that an object is typically male or female when the majority of students associates a gender to it. According to this criterion we observe that among 167 objects studied, only 14 are considered typically male by all the groups: balloon, belt transmission, rubber tyre, pump, screwdriver, tractor, drill, motor, hammer, axe, soldering iron, bike rear derailleur. But at 14 years hold, for girls, masculine objects are significantly more numerous. At this previous list girls of 14 years hold add 14 other objects: plane, truck, open end wrench, electronics component, bike speedometer, Swiss army knife, scale, Gameboy, copper plate, tower crane, metal file, gamepad, clamp, backhoe loader. Among these 167 objects, only 4 are considered typically female by all the groups: pastry molds, order form, tablecloth, and pair of boots. In addition for boys, there are 2 others typically feminine objects: pan and sales catalogue.

\section{Data by artifacts categories}

To organize the results presentation, data are now gathered under major categories: tools and instruments; ITC; transport; electric objects; gears and machines; food; utensils; home and a category others objects. This classification is one among other possible. Indeed, contrary to what is done in the field of life object, there is no academic classification of

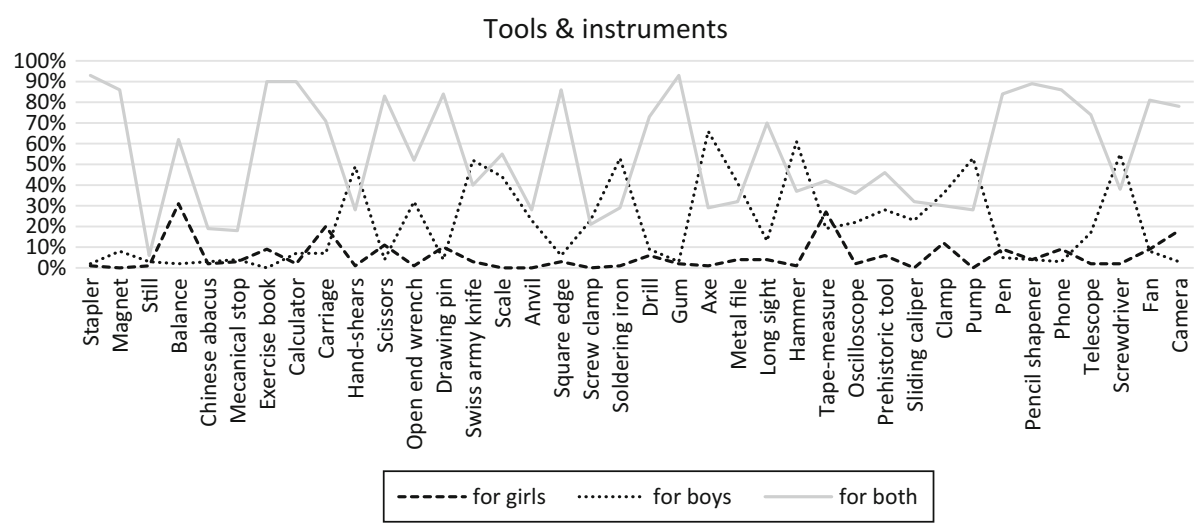

Fig. 1 Tools and instruments' family 
artifacts in technology. Technology artifacts can be categorized based on a lot of criteria (use, material, application domains, professional jobs, type of technology, etc.).

\section{Tools and instruments}

Among the 38 items grouped in this family (see Fig. 1), many are considered very predominantly as "for both": stapler, magnet, exercise book, calculator, scissors, drawing pin, square edge, drill, gum, pen, pencil sharpener, phone, telescope, fan, camera. These neutral artifacts are therefore primarily tools used in everyday life. We observe that seven tools or instruments are in majority perceived as masculine: hand-shears, Swiss army knife, soldering iron, axe, hammer, pump, and screwdriver. These objects refer to technical activities actually carried out by men. We see that only two tools are considered as more feminine than masculine: the balance and the tape-measure. These artifacts are probably linked to feminine occupation (sewing, food or health care).

ITC

The neutral character of ITC objects is more obvious. The majority of gendered responses involve less than $15 \%$ of judgments (see Fig. 2). Only two objects show a difference between boys and girls: hard drive and central processing unit are significantly seen to be more masculine than feminine. When you are in the software (use activities) the tendency would be rather neutral and when you are in the hardware the tendency would be more masculine.

\section{Transportation}

Among the 25 artifacts of this family, 16 are considered non-gendered: car, plane, boat, bus, motorcycle helmet, brake, hot air balloon, bike lamp, dash board, child's scooter, train, tramway, bicycle, sailboat, remote, steering wheel. Despite this, all means of transport are seen as more masculine than feminine (Fig. 3).

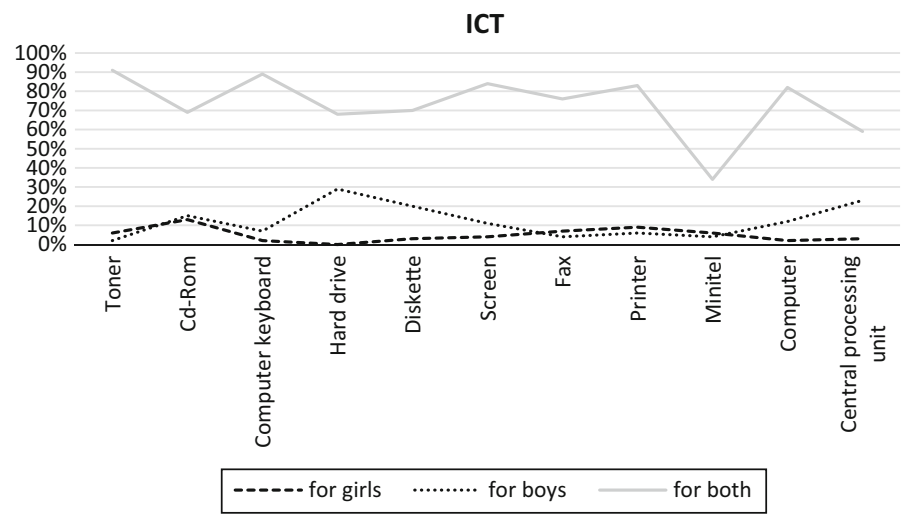

Fig. 2 ITC family 


\section{Transportation}

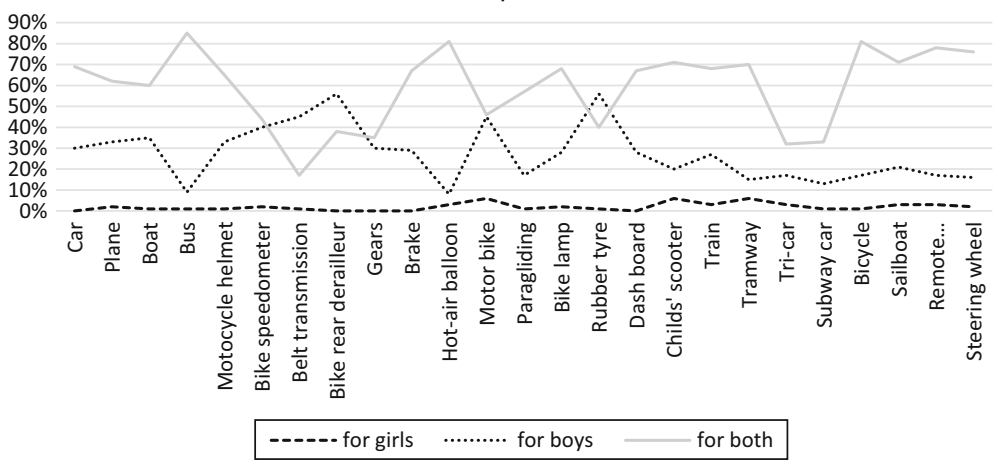

Fig. 3 Objects of transport family

\section{Electric}

Among the 16 objects grouped here only 7 are massively seen as mixed (or neutral): light bulb, batteries case, loudspeaker, switch, flash light, battery, indicator light. Despite this result, we see that there are more answers for boys than for girls, expet for 2 objects largely unknown by pupils (photo-tray and template) (Fig. 4).

\section{Gears and machines}

Of the 15 objects of this family (see Fig. 5) only 4 are primarily considered to be mixed: typewriter, videotapes, television and bending machine. Six are massively judged as masculine: truck, tower crane, motor, drilling machine, excavator and tractor. These machines are associated to professional activities for men. For the others artifacts differences are less important.

\section{Food}

The mixed character of food objects gives a strong consensus. But pupils think that girls are more concerned with chocolate and egg boxes and boys with frozen food and drinks can (Fig. 6).

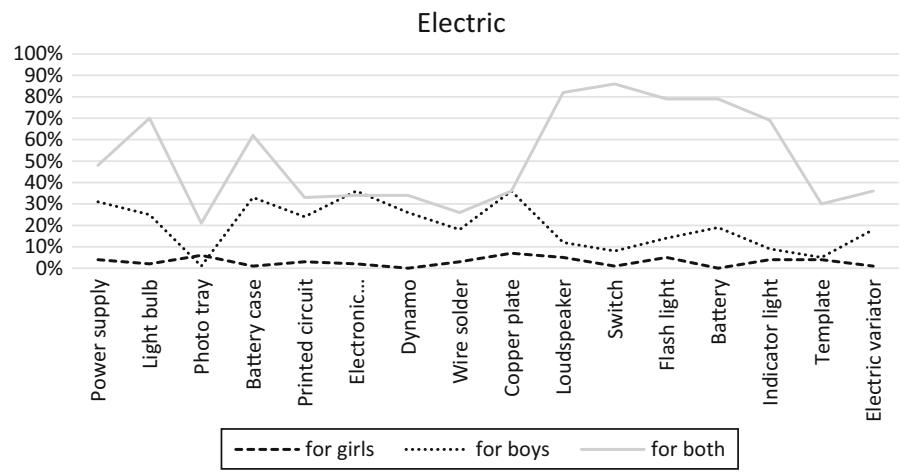

Fig. 4 Electric family 


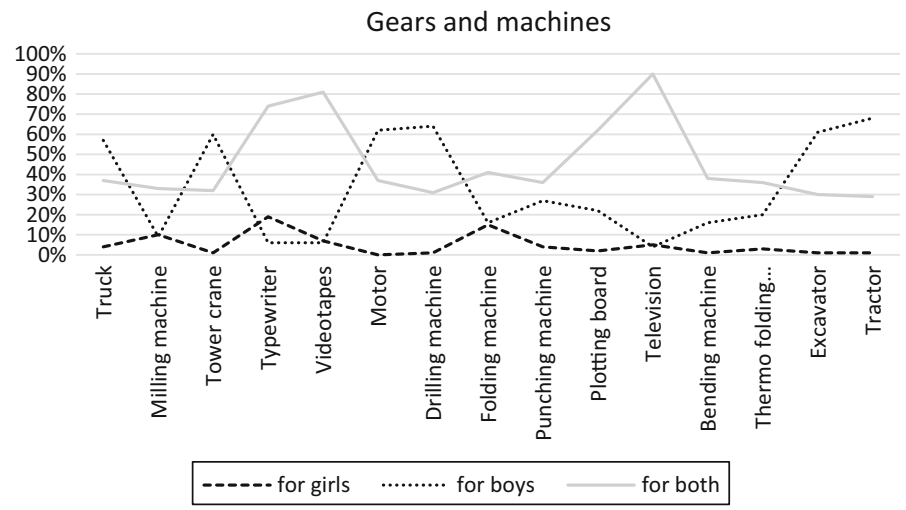

Fig. 5 Machine family

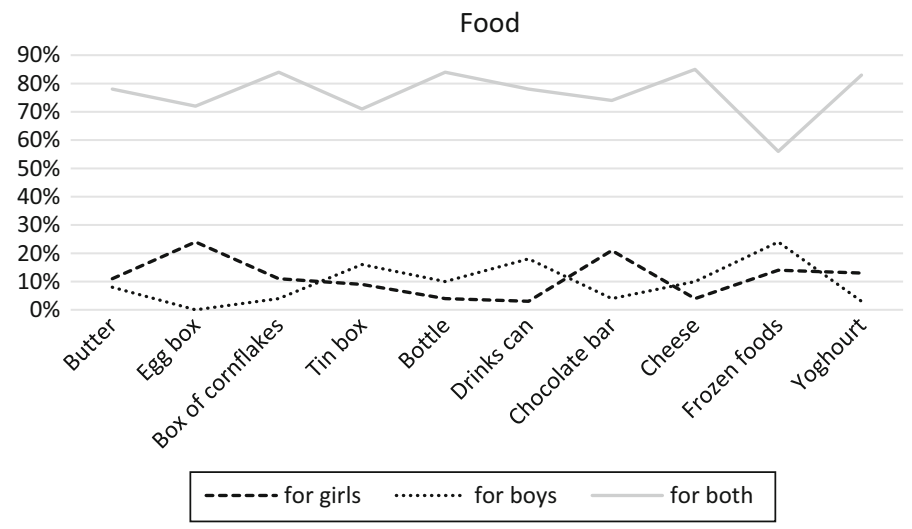

Fig. 6 Food family

\section{Home}

Objects of this family are mainly mixed (see Fig. 7): plate, basin, barrel, bowl, cover of table, cup, tube of glue, glass, cupboard, barrier, coffee machine, sofa, cardboard box, chair, heating, hanger; toaster, house, clock, dining table, stool. Unlike the previous results, we observed that the domestic utensils are most often attributed to girls than boys except for barrel and barrier. Two are typically feminine: pastry molds and tablecloth, and in a less proportion the pan and sales catalog. These results confirm the internalization by students of the usual stereotypes that associate domestic activities with women.

\section{Others}

In this category, six objects relate to clothes and professional protections (windbreaker, soundproof helmet, shoes, pair of gloves, safety goggles, fashion boots). All of them are largely seen as mixed except the fashion boots. Eight objects belong to the field of the sport and leisure. Three of them (balloon, game boy and joystick are significantly considered to 


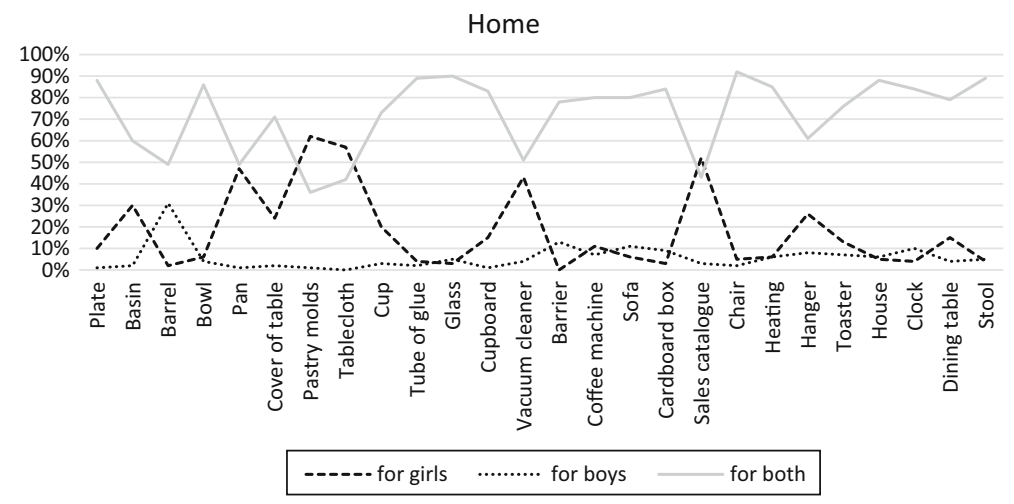

Fig. 7 Home

be more male than female. We note that among them the newspaper is more male $(28 \%$ against $2 \%$ ) contrary to the rather female book ( 20 vs $3 \%$ ). The purchase order is also significantly marked female (35 vs $6 \%$ ) (Fig. 8).

\section{Temporal evolution of the artifacts represented in the schoolbooks}

It is noted that only eight objects are co-present in the four successive textbooks (1986, 1996, 2000, 2005): tape measure, computer, oscilloscope, drilling machine, bicycle, car, sliding caliper.

Eight artifacts appear in the last three textbooks: bottle, printed circuit, shears, scissors, Screw clamp, rubber tyre, bending machine and screwdriver. Four are present in the two last years: house, shoes, square edge and glass. Nine are present in 1996 and 2005 but absent in 2000: camera, sailboat, truck, open end wrench, bike rear derailleur, drill, loudspeaker, pawn of game and stool.

Finally, 24 objects appear in 2005 for the first time: plane, balance, windbreaker, bus, Bike speedometer, belt transmission, hang glider, gears, brake, toboggan, hot air balloon, motor, pen, dash board, child's scooter, Eiffel tower, tractor, train, tramway, tri-car,

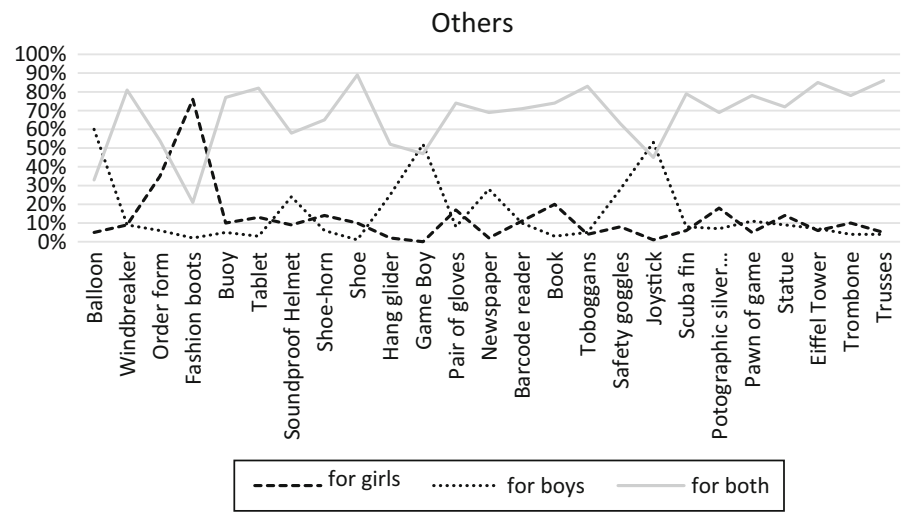

Fig. 8 Others 
subway car, steering wheel. Thus, among them there is a majority of artifact linked to transport, which is coherent with the introduction in 2005 of this topic in French curriculum for 11-12 years old. However we observe that the artifacts related to transport are often seen as masculine. Introducing a specific thematic of knowledge, therefore, includes the risk of enhancing the girls' lack of interest in technology education.

So when new artifacts are introduced, others disappear as objects related to the field of electronics and mechanics that occupied a dominating place in 1985-2005. But we note also the elimination of many heteroclite objects which were very important to reflect the diversity and extent of the cultural dimension of the technical environment. Thus, the first textbooks gave a broad impression of technology with representatives from many classes of artifacts : furniture (dining table, chair...,) means of communication (television, newspaper), food products, (tin box, drink can,...), home equipment (pan, tablecloth, vacuum cleaner, pastry molds...), computer and calculation tools (CD-ROM, hard drive, computer), usual hand tools (hammer, screwdriver...), gears (crane, excavator), toys (joystick, Game Boy, balloon...) and buildings (statue; Eiffel tower). The later, more recent textbook, gave a narrower depiction of technology.

Thus, we see that a certain number of typically male objects disappear (crane, range servant boy, balloon...). The same applies to rare items typically feminine (tablecloth, pastry molds, pan...). In this respect we can consider that the supports of study have increased in neutrality in terms of gender and best balance of girls and boys interest. We hope that the diversity of the thematic studied at this level succeeds in compensating the loss of variety and richness of study supports involved. This should be the case, at least in part, because the thematic of architectural design and domotic (home automation) are introduced a year later for the 13-14 years old.

\section{Conclusion}

This study show the student perception of the gendered nature of many material artifacts that illustrate French schoolbooks of technology for 12-14 years old. The majority of artifacts implicated are neutral, but those that are gendered are more masculine than feminine marked. This factor is likely to strengthen the girls feeling that teaching of technology is more adapted for boys than for girls. It is therefore one of the possible barriers that contribute to the disaffection of the technology cursus by girls. In addition, we saw that between 12 and 14 years old the number of objects regarded as male gendered increases significantly for girls. This shows that the internalization of gender stereotypes is strengthened under the effect of age.

We see also that students did not recognize a significant number of artifact named in the list presented. Probably it would be more relevant to present both pictures and words of these objects, rather than a list of words. But we note also that unknown objects remain with age in the same proportion for girls and decrease for boys.

Nevertheless, our results, converge with the observations of Weber and Custer (2005) upon an evolution of technology education contents more balanced in regards of both boys' and girls' interests: "Even if the topics presented in technology education appear to be inherently more interesting to males, the development of gender-balanced appears to overcome the differences in topical interest activities" (p. 67).

These study should draw the attention of the curriculum designers and the editors of textbooks. The concept of parity should also apply to this question. Indeed, if it is difficult 
to refer only to non-gendered objects, it would be advisable to balance the number of 'male' and 'female' objects. Moreover, teachers are still often free to choose their supports of study. Therefore, they would benefit with being formed with this question of gender. "Teachers must not only learn how to choose a textbook, but also how to teach in a genderinclusive way" (Mottier 1997, p 28).

However, technological areas of women interest are numerous: technologies related to health and its prevention, to meatpacking, to cosmetology, to dressmaking and accessories, etc. Areas that are not taken into account in the curricula!

But for each theme, the selection of instructional materials remain decisive. It is obvious that girls have many affinities with topic such as home automation and interior design. But if this topic remain focused on artifacts such as the automatic gate or electrical installation, girls could not be very motivated.

\section{Appendix}

Excerpt from the book Butler (1990). Gender trouble-feminism and the subversion of identity, preface, viii-ix. "The foundational categories for sex, gender, and desire as effects of a specific formation of power requires a form of critical inquiry that Foucault, reformulating Nietzsche, designates as "genealogy." A genealogical critique refuses to search for the origins of gender, the inner truth of female desire, a genuine or authentic sexual identity that repression has kept from view; rater, genealogy investigates the political stakes in designating as an origin and cause those identity categories that are in fact the effects of institution, practices, discourses with multiple and diffuse point of origin. That task of this inquiry is to center on-and decenter-such defining institutions: phallogocentrism and compulsory heterosexuality".

\section{References}

Akrich, M. (1992). The description of technical objects. In W. E. Bijker \& J. Law (eds.), Shaping technology/building society, studies in sociotechnical change (pp. 205-224). Cambridge: MIT Press.

Akrich, M. (1995). User representations: Practices, methods and sociology In A. Rip, T. J. Misa, and J. Schot (eds.), Managing technology in society: The approach of constructive technology assessment (pp.167-184). London: Pinter Publishers.

Autio, O. (2013). When talent is not enough: Why technologically talented women are not studying technology. Journal of Technology Education, 24(2), 14-30.

Baudelot, C., \& Establet, R. (1992). Allez les filles!. Paris: Le seuil.

Berg, A. J., \& Lie, M. (1995). Feminism and construtivism: Do artifact have gender? Sciences, Technology and Human Values, 30(3), 332-351.

Bijker, W. E. (1995). Of bicycles, bakelites, and bulbs-Toward a theory of sociotechnical change. Cambridge, MA: The MIT Press.

Blumberg R. L. (2007). Gender bias in textbooks: A hidden obstacle on the road to gender equality in education. Background paper for the education for all global monitoring report 2008: Education for all by 2015: Will we make it? UNESCO: 2008/ED/EFA/MRT/PI/18.

Bose, C. E., \& Peter, H. R. (1983). Gender and jobs: Prestige standings of occupations as affected by gender. American Sociological Review, 48(3), 316-330.

Boudon, R. (1973). L'inégalité des chances. Paris: Armant Colin.

Bourdieu, P., \& Passeron, J. C. (1970). La reproduction. Eléments pour une théorie du système d'enseignement. Paris: Edition de Minuit.

Brugeilles, C., \& Cromer, S. (2011). genre et mathématiques dans les images des manuels scolaires en France. Trema, 35-36, 142-154.

Butler, J. (1990). Gender trouble: Feminism and the subversion of identity. London: Routledge. 
Caleb, L. (2000). Design technology: Learning how girls learn best. Equity \& Excellence, 33(1), 22-25.

Caravita, S., Valente, A., Luzi, D., Pace, P., Kahlil, I., Berthou, G., \& Clément, P. (2008). Construction and validation of textbook analysis grids for ecology and environmental education. Science Education International, 19(2), 97-116.

Castéras, J., Clément, P., Abrougui, M., Sarapuu, T., Turcinaviciene, J., Aggoram, B., \& Carvalho, G. (2008). Genetic determinism in school textbooks, a comparative study conducted among 16 countries. Science Education International, 19(2), 163-184.

Chatoney, M., \& Andreucci, C. (2009). How study aids influence learning and motivation for girls in technology education. International Journal of Technology and Design Education, 19(4), 393-402.

Cockburn, C., \& Ormord, S. (1993). Gender and technology in the making. London: Sage Publications Ltd.

Dagiral, E. (2006). Genre et technologie. Terrains et travaux, 1(10), 194-206.

Duru-Bellat, M. (2005). L'école des filles, quelle formation pour quels rôles sociaux? Paris: l'Harmatan.

Evan, L., \& Davies, K. (2000). No sissy boys here: A content analysis of representation of masculinity in elementary school reading textbooks. Sex Roles: A Journal of Research, 42(3-4), 255-270.

Ezzell, M. B. (2009). Barbie dolls on the pitch: Identity work, defensive othering, and inequality in women's rugby. Social Problems, 56, 111-131.

Fleer, M., \& Jane, B. (2004). Technology for children: Research based approaches (2nd ed.). Australia: Pearson Prentice Hall.

Gill, R., \& Grint, K. (1995). The gender technology relation: Contemporary theory and research. In K. Grint \& G. Rosalind (Eds.), The gender-technology relation-contemporary theory and research (pp. 1-28). Bristol: Taylor \& Francis.

Ginestié, J. (2005). Filles ou garçons, seuls ou à deux : Quelle influence sur les activités de production en éducation technologique ? Aster, 41, 217-241.

Griffin, S. (1984). Woman and nature: The roaring inside her. London: The women's Press.

Grint, K., \& Rosalind, G. (1995). The gender technology relation-contemporary theory and research. Bristol: Taylor \& Francis.

Harding, S. \& McGregor, E. (1996). The gender dimension of science and technology. The conceptual frameworks, in World Science Report, (pp. 301-305), Paris, London: UNESCO publishing.

Jackson, S., \& Gee, S. (2005). Look Janet, no you look John: Construction of gender in early school reader illustrations across 50 years'. Gender education, 17(2), 115-128.

Knopke, V. (2014). Theoretical implications of gender for technology education. Australian Journal of Technology Education, 1, 20-28.

Law, J. (1991). Introduction: Monster, machines and sociotechnical relations. In J. Law (Ed.), A sociology of monsters: Essays on power, technology and domination (pp. 1-23). London and New York: Routledge.

Latour, B. (1987). Science in action. Milton Keynes: Open University Press.

Lorber, J. (1994). Paradoxes of gender. New Haven, CT: Yale University Press.

Lorenzi-Cioldi, F. (1991). Self-stereotyping and self-enhancement in gender groups. European Journal of Social Psychology, 21, 403-417.

Marry, C. (2004). Le sexe des études : Permanence et changements. In M. Perrot (Ed.), Quelle mixité pour l'école? (pp. 37-46). Paris: Albin Michel.

McKenzie, D., \& Wagcman, J. (1999). The social shaping of technology. Maidenhead, Philadelphia: Open University Press.

Mosconi, N. (1994). Femmes et savoir. La société, l'école et la division sexuelle des savoirs. Paris: l'Harmattan.

Mosconi, N., \& Delanote, R. (2003). C'est technique, est-ce pour elles? Travail, Genre et Sociétés, 1(9), 71-90.

Mottier, I. (1997). She in textbooks. Equal presence of women and man in educational materials. Enschede: The national institute for curriculum development.

Nisbet, M., Pendergast, D. L., \& Reynolds, J. (1998). Keeping gender on the technology education agenda: An issues paper. Journal of the Home Economics Institute of Australia, 5(1), 23-32.

Oakley, A. (1972). Sex, gender and society. London: Temple Smith.

Oldenziel, R. (2003). Why masculine technologies matter. In N. E. Lerman, R. Oldenziel, \& A. Mohun (Eds.), Gender and technology (pp. 37-71). Maryland: Johns Hopkins University Press.

Oudshoorn, N., Rommes, E., \& Stienstra, M. (2004). Configuring the user as everybody: Gender and design cultures in information and communication technologies. Science, Technology and Human Values, 29(1), 30-64.

Persson, I. H. (2010). Do artefacts reflect our thinking about gender? In H. Middleton (Ed.), Knowledge in technology education (pp. 178-185). Brisdane: Australia. Griffith Institute for Educational Research.

Petrina, S. (2007). Advanced teaching methods for the technology classroom. Hershey: Information, Sciences, International. 
Rosenwald, F. (2006). Filles et garçons dans le système éducatif depuis vingt ans. In Données sociales. La société française, Education, formation, 2, 87-93.

Rothschild, J. (1988). Teaching technology from a feminist perspective: A practical guide. New York: Pargamon Press Inc.

Roustan-Jalin, M., Ben Mim, H., \& Dupin, J.-J. (2002). Technologie, sciences, filles, garçons: Des questions pour la didactique ? Didaskalia, 21, 9-42.

Ruel-Traquet, S. (2010). Filles et garçons. Loisirs culturels et différenciation de genre dans l'enfance. Enfance \& Cultures Actes du colloque international 9es Journées de sociologie de l'enfance, Paris. http://www.enfanceetcultures.culture.gouv.fr/.

Sadker, D., \& Silber, E. S. (2007). Gender in the classroom: Foundations, skills, methods, and strategies across the curriculum. New Jersey: Lawrence Erlbaum Associates.

Schultz, P. W., Oskamp, S., \& Mainieri, T. (1995). Who recycles and when? A review of personal and situational factors. Journal of Environmental Psychology, 16, 106-121.

Simon, R. W., \& Leda, E. N. (2004). Gender and emotion in the U.S.: Do men and women differ in selfreports of feelings and expressive behavior? American Journal of Sociology, 109, 1137-1176.

Stanley, A. (1993). Mothers and daughters of invention: Notes for a revised history of technology. In J. Hopkins (Ed.), Sex/machine (p. 708). Bloomington: Indiana University Press.

Turja, L., Endephlsulpe, M., \& Chatoney, M. (2009). A conceptual framework for developing the curriculum and delivery of technology education in early childhood. International Journal of Technology and Design Education, 19, 353-365. doi:10.1007/s10798-009-9093-9.

UNESCO Report. (2007). Science, technology and gender: An international report. Paris: UNESCO Publishing.

Wajcman, J. (2000). Reflexions on gender and technology studies: In what state is the art? Social Studies of Science, 30(3), 447-464.

Wajcman, J. (2004). TechnoFeminism. Cambridge, UK: Polity Press.

Weber, K., \& Custer, G. (2005). Gender-based preferences toward technology education content, activities, and instructional methods. Journal of Technology Education, 16(2), 55-69.

World science report-UNESCO (1996). The gender dimension of science and technology. http://www. unesco.org/new/en/natural-sciences/science-technology/prospective-studies/unesco-science-report/ worldsience-report-1996.

Zuga, K. F. (1996). Reclaiming the voices of female and elementary school educators in technology education. Journal of Industrial Teacher Education, 33(3), 1-11. 